\title{
ПЕРСПЕКТИВЫ НЕФТЕГАЗОНОСНОСТИ ДОЮРСКИХ ОТЛОЖЕНИЙ СЕВЕРНОГО СКЛОНА БУЗАЧИНСКОГО ПОДНЯТИЯ
}

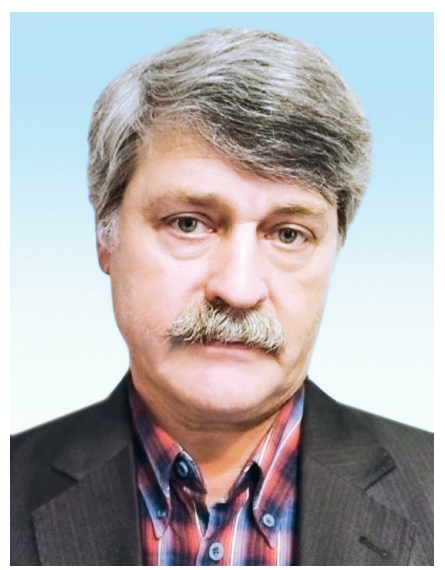

А.П. ПРОНИН ${ }^{1}$, заведующий отделом геологического анализа, https://orcid.org/0000-00021285-5255

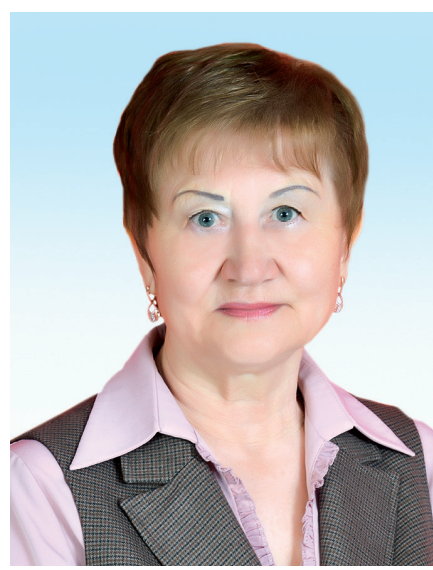

Л.В. ШЕСТОПЕРОВА*2, директор департамента геологии, кандидат геол.-мин. наук, https://orcid.org/ 0000-00029187-6539

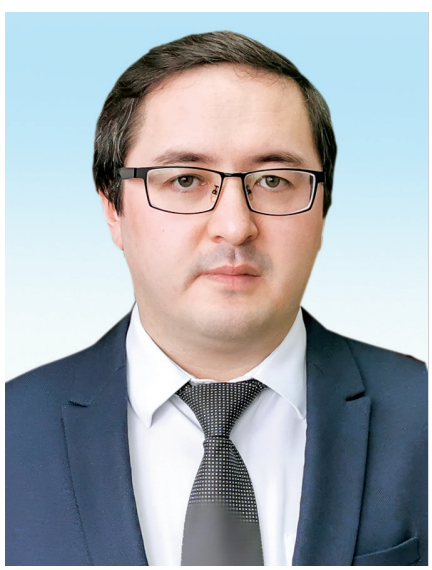

A.M¥HAPA ${ }^{2}$ директор, доктор геол.-мин. наук, https://orcid.org/0000-00015658-4007

${ }^{1}$ TOО «КАЗКОРРЕСЕЧ»

Республика Казахстан, 060026, г. Атырау, Северная промзона, 32

2КАЗАХСКИЙ НАУЧНО-ИССЛЕДОВАТЕЛЬСКИЙ ГЕОЛОГОРАЗВЕДОЧНЫЙ НЕФТЯНОЙ ИНСТИТУТ Республика Казахстан, 060011, г. Атырау, ул. Айтеке-би, 43

Анализ геолого-сейсмических материалов по Бузачинскому поднятию и прилегающим территориям показал бесперспективность домезозойских отложений в его сводовых частях. Артинско-каменноугольные карбонатно-терригенные отложения, вскрытые параметрическими и глубокими скважинами на Бузачинском своде, характеризуются значительной плотностью и метаморфизмом, отсутствием в разрезе нефттематеринских пород. Дальнейшие перспективы этого региона связываются с северо-западным и северным склонами Бузачинского поднятия, зоной сочленения Прикаспийской впадины и Туранской плиты.

КЛЮЧЕВЫЕ СЛОВА: Бузачинское поднятие, карбонатная платформа, палеозойские отложения, формирование залежей, перспективы нефтегазоносности.

\section{ЮРАҒА ДЕЙІНГТ СОЛТҮСТІК БЕТКЕЙ ШӨГІНДІЛЕРІНІҢ БОЗАШЫ КӨТЕРІЛІМІНІҢ МҰНАЙ-ГАЗДЫЛЫҒЫ ПЕРСПЕКТИВАЛАРЫ}

А.П. ПРОНИН ${ }^{1}$, Геологиялық талдау бөлімінің бастығы, https://orcid.org/0000-0002-1285-5255

Л.В. ШЕСТОПЕРОВА ${ }^{2 *}$, Геология департаментінің директоры, геология және минералогия ғылымдарының кандидаты, https://orcid.org/0000-0002-9187-6539

A. M¥HAPA ${ }^{2}$, директор, геология және минералогия ғылымдарының докторы, https://orcid. org/0000-0001-5658-4007

\footnotetext{
* Адрес для переписки. E-mail: lara.shestoperova@mail.ru
} 
${ }^{1}$ «КАЗКОРРЕСЕЧ» ЖШС

Қазақстан Республикасы, 060026, Атырау қаласы, Солтүстік индустриалды аймақ, 32

«ҚАЗАҚ ҒЫЛЫМИ-ЗЕРТТЕУ ГЕОЛОГИЯЛЫҚ БАРЛАУ МҰНАЙ ИНСТИТУТЫ» Қазақстан Республикасы, 060011, Атырау қаласы, Әйтеке би көшесі, 43

Бозашы көтерілімі және оған іргелес аумақтардың дөңес бөліктері бойынша геологиялық-сейсмикалық материалдарды талдау мезозойға дейінгі шөгінділерінің перспективасыздығын көрсетті. Бозашы дөңес көтерілімінде параметрлік және терең ұңғымалармен ашылған Артин-карбон карбонатты-терригендік шөгінділерінің айтарлықтай тығыздығы және метаморфозмімен, қимасында мұнайтуындатушы жыныстардың болмауымен сипатталады. Бұл аймақтың болашақ перспективалары Бозашы көтерілімінің солтүстік-батыс және Солтүстік беткейлерімен, яғни Каспий маңы ойпаты мен Тұран плитасының түйісу аймағымен байланысты.

ТҮЙІн СӨзДЕР: Бозашы көтерілімі, карбонатты платформа, палеозой шөгінділері, шоғырлардың қалыптасуы, мұнайгаздылық перспективалары.

\section{OIL-AND-GAS POTENTIAL OF THE PRE-JURASSIC DEPOSITS OF THE NORTHERN SLOPE OF THE BUZACHINSKY UPLIFT}

A.P. PRONIN 1 , Head of the Geological Analysis Department, https://orcid.org/0000-0002-1285-5255 L.V. SHESTOPEROVA ${ }^{2 *}$, Director of the Geological Department, Candidate of Geological and Mineralogical Sciences, https://orcid.org/ 0000-0002-9187-6539

A.MUNARA ${ }^{2}$, Director, Doctor of Geology and Mineralogy, https://orcid.org/0000-0001-5658-4007

${ }_{1}$ «KAZCORERESEARCH» LLP

32, Severnaya promzona, Atyrau city, 060026, Republic of Kazakhstan,

${ }^{2}$ KAZAKH GEOLOGICAL EXPLORATION PETROLEUM INSTITUTE

43, Aiteke bi Street, Atyrau city, 060011, Republic of Kazakhstan

The analysis of geological and seismic materials on the Buzachinsky uplift and adjacent areas showed the lack of prospects of pre-Mesozoic deposits in its upper zones of formation. The Artinskian-carboniferous carbonate-terrigenous deposits exposed by parametric and deep wells in the Buzachinsky arch are characterized by significant density and metamorphism, the lack of source rocks in the rock section. Further prospects of this area are associated with the north-western and northern slopes of the Buzachinsky uplift, as well as the junction zone of the Pre-Caspian depression and the Turanian Plate.

KEY WORDS: Buzachinsky uplift, carbonate platform, Paleozoic deposits, formation of deposits, oil and gas potential.

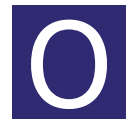

дной из актуальных проблем нефтяной геологии в настоящее время является нефтегазоносность доюрских отложений молодых платформ. В последние годы все исследователи сходятся во мнении о перспективности нижних горизонтов осадочного чехла молодых плит и необходимости постановки целенаправленных нефте-газопоисковых работ, особенно в районах, где фонд перспективных структур в мезозойском комплексе исчерпан либо близок к этому. К числу таких районов относится и территория полуострова Бузачи, где на северных прилегающих территориях Северного Каспия прогнозируется развитие карбонатных подсолевых структур [1-5]. Первые сейсмические работы на полуострове Бузачи велись Гурьевской, Турланской и Илийской геофизическими экспедициями в семидесятые годы. Объектом изучения являлись юрско-меловые отложения, на которых одновременно 
проводилось структурно-поисковое и глубокое бурение. Этот комплекс исследований позволил открыть в нижнемеловой и среднеюрской толщах месторождения нефти и газа Каражанбас, Северные Бузачи, Жалгызтобе, Арман, Каламкас, Каражанбас Северный, Каратурун Морской, Каратурун Восточный, которые сосредоточены, преимущественно, в северной части Бузачинского поднятия (рисунок 1).

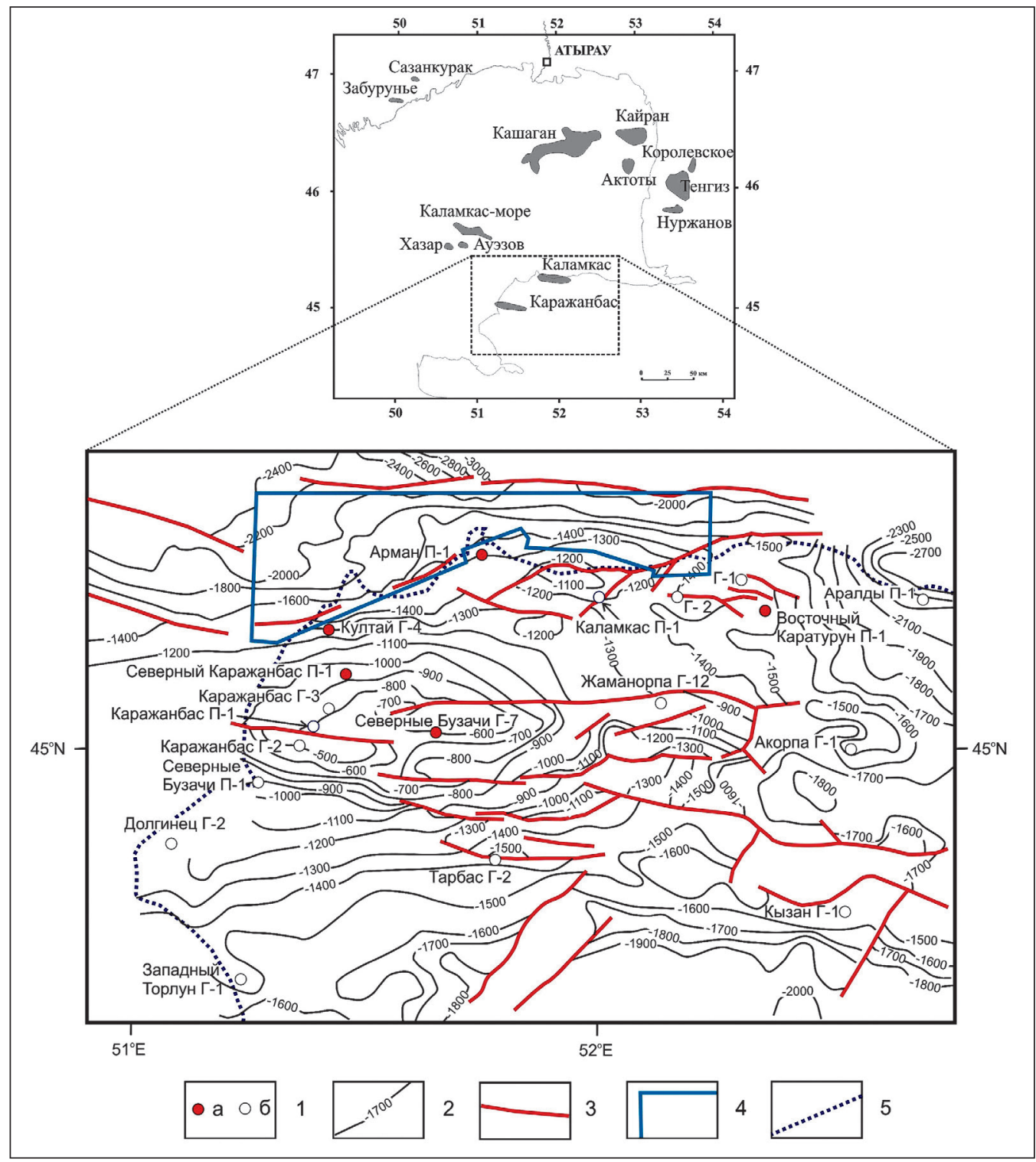

Рисунок 1 - Структурная карта по кровле доюрских отложений на Бузачинском поднятии (V отражающий горизонт)

1 - а) скважины, вскрывшие палеозойские отложения; б) скважины, вскрывшие триасовые и верхнепермские отложения; 2 - изогипсы доюрских отложений (V отражающий горизонт); 3 - разломные нарушения, 4 - граница морского геолого-разведочного блока C2; 5 - граница Каспийского моря 
Продуктивные горизонты залегают на небольших глубинах - от 300 до 1000 м. Примечательно, что залежи нефти и газа на южном склоне свода не выявлены.

Нефть бузачинской нефти - плотная, смолистая, с большим содержанием серы и ванадия.

По данным детальных геохимических исследований, она является производной органического вещества морского типа, претерпевшая потерю легких фракций и окисление [6]. Наиболее биодеградированная и измененная нефть установлена на месторождении Каражанбас, где диапазон глубин залегания продуктивных горизонтов находится в пределах 228-446 м. В гипсометрически более погруженных северных частях Бузачинского поднятия разрез юрско-меловых отложений наращивается, в разрезе увеличивается количество продуктивных пластов, плотность нефти уменьшается, появляются газовые залежи (месторождения Каламкас, Арман). Техника и технология сейсморазведочных работ прежних лет не способствовали изучению палеозойского комплекса отложений - на временных сейсмических разрезах просматривались лишь непротяженные отражающие площадки.

С целью изучения палеозойских отложений в 1970 - 1990-х гг. на Бузачинском поднятии пробурены три параметрические скважины - Северный Каражанбас П-1, Восточный Каратурун П-1, Арман П-1, а также две глубокие - Северные Бузачи Г-7, Култай Г-4, которыми вскрыты отложения верхнего девона, нижнего, среднего-верхнего карбона и нижней-верхней перми (рисунок 2).

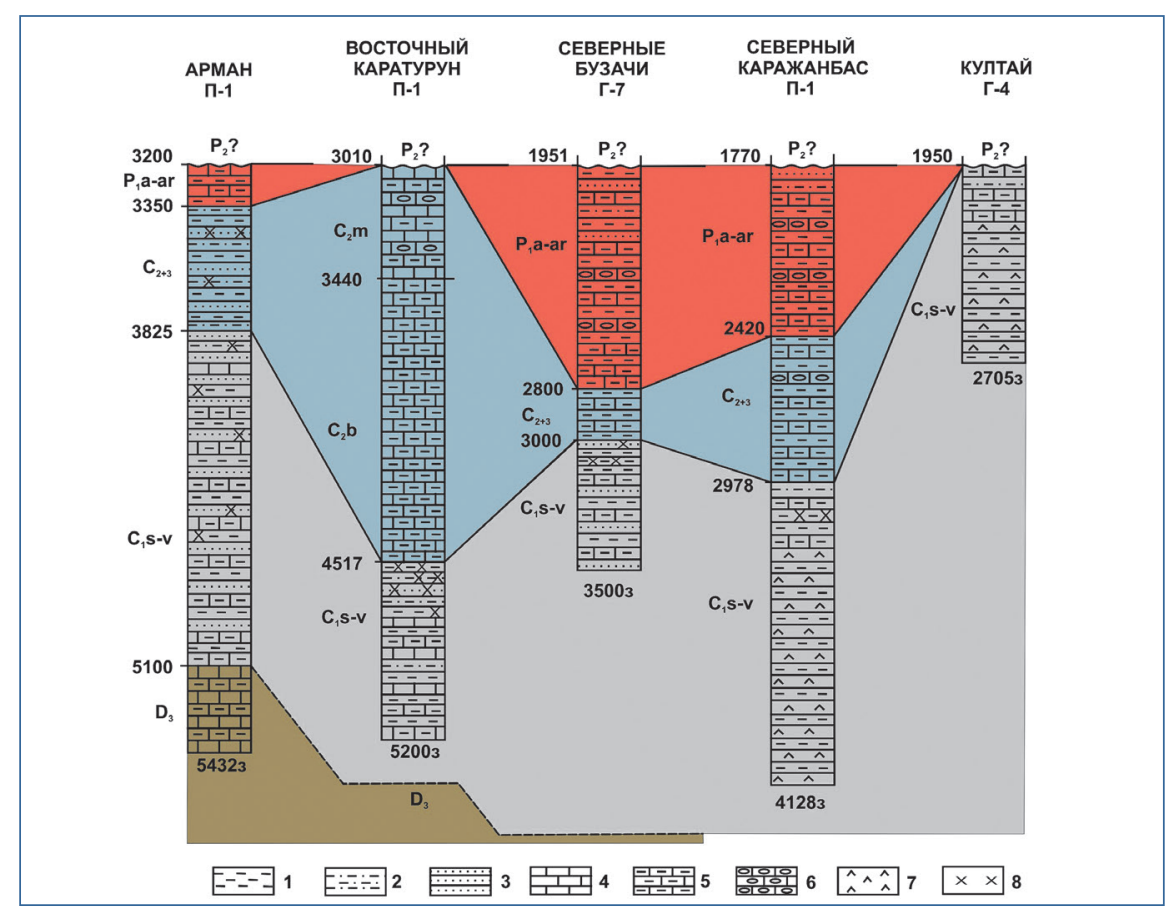

Рисунок 2 - Сопоставление палеозойских отложений, вскрытых скважинами на Бузачинском поднятии

1 - аргиллиты; 2 - алевролиты; 3 - песчаники; 4 - известняки; 5 - известняки глинистые; 6 - известняки обломочные; 7 - андезитовые порфририты; 8 - примесь пирокластического материала 
Скважины Северные Бузачи Г-1, Каламкас П-1, Каражанбас Г-2, Г-3 вскрыли на забое отложения, предположительно, верхней перми (рисунок 3). Литолого-биостратиграфические особенности доюрских отложений изучали К.В. Виноградова, Д.А. Кухтинов, В.В. Липатова, А.П. Пронин, М.А. Серебрянская [7-12]. Одной из характеристик триас-палеозойских отложений является небольшая глубина кровли триасовых отложений в пределах Бузачинского поднятия - не более 1500 м, а уже в разрезах Северо-Устюртской впадины кровля этих отложений встречена уже на глубине 3000 м и более.

Верхнедевонские отложения вскрыты только скважиной Арман П-1 в интервале 5100-5432 м (забой), которые освещены небольшим количеством керна. По данным литолого-петрографических исследований, отложения верхнего девона в интервале 5183-5191 м представлены чередованием алевролита серого, аргиллита темно-серого и известняка (мадстоуна) светло-серого цвета, участками перекристаллизованного, трещиноватого, ниже в интервале 5300-5307 м встречен известняк (грейнстоун).

Нижнекаменноугольные отложения сложены карбонатно-аргиллитово-вулканогенной толщей, в составе которой (особенно в ее нижней части) преобладают вулканогенные породы, представленные андезитовыми, реже - кварцевыми пор-

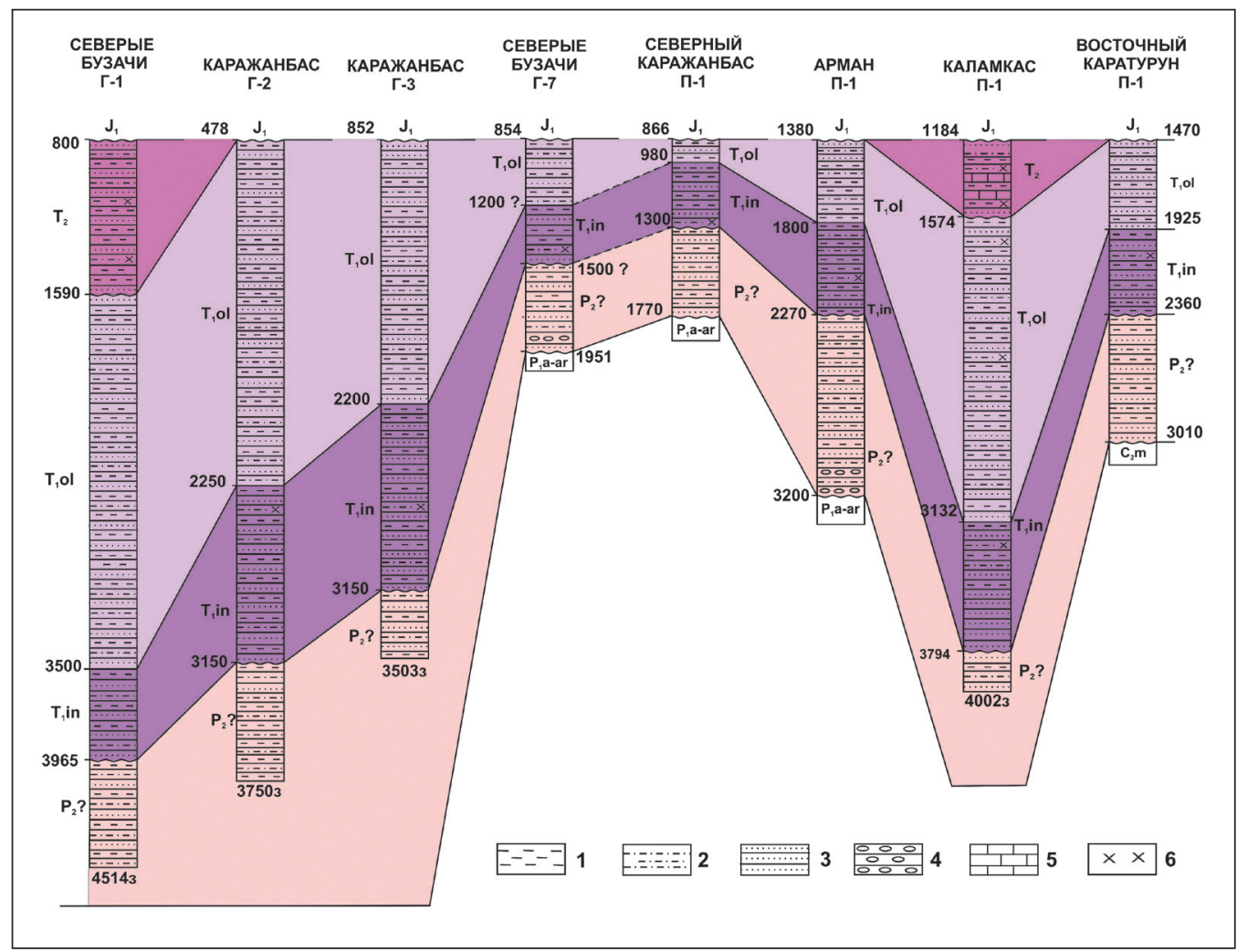

Рисунок 3 - Сопоставление верхнепермских и триасовых отложений, вскрытых скважинами на Бузачинском поднятии

1 - аргиллиты; 2 - алевролиты; 3 - песчаники; 4 - конгломераты; 5 -известняки; 6 - примесь пирокластического материала 
фиритами. Эти породы, судя по каротажу, образуют покровы толщиной от 10-16 до 58-156 м, которые чередуются с пачками глинисто-карбонатных пород (аргиллитов, известняков, мергелей и карбонатизированными туфами). Толщина этих пачек колеблется в пределах 10-36 м, иногда достигает 48 м. Покровы вулканогенных пород по своему строению - неоднородны, большинство их (особенно крупные) расслоены пачками глинисто-карбонатных разностей.

Среднекаменноугольные отложения выявлены в скважине Восточный Каратурун П-1, где они присутствуют в составе башкирского и московского ярусов. Башкирские отложения представлены чередованием известняков - мадстоунов и вакстоунов темно-серых, почти черных и серых с коричневым оттенком, с содержанием скелетных зерен, среди которых - членики криноидей, фораминиферы, водоросли, обрывки мшанок, остракоды, оолиты, пеллеты, кремнистые спикулы губок трещиноватых, микрослоистых, окремненных, со стилолитами, выполненными глинисто-битуминозным веществом черного цвета, слабопиритизированными, слабодоломитистыми. Московские отложения сложены чередующимися известняками темно-серыми, окремнелыми, очень крепкими, плотными, монолитными, с вертикальными и наклонными трещинами (2-3 мм), участками с кальцитом, с известняками обломочными, часть которых доломитизирована, темно-серого цвета, с фузулинидами и желваками водорослей участками с редкими гальками кремнистых пород гравийной размерности. В разрезе скважины Восточный Каратурун П-1 толщина башкирских отложений составляет 1077 м, московских - 430 м. В остальных скважинах дать более дробное расчленение разрезов среднего-верхнего карбона не представляется возможным, они представлены неравномерно, местами ритмично переслаивающимися известняками, мергелями и аргиллитами.

Верхнекаменноугольные отложения, всего вероятней, отсутствуют по причине преднижнепермского размыва.

Нижнепермские отложения - толща неравномерно, местами ритмично переслаивающихся известняков, мергелей и аргиллитов с незначительным преобладанием аргиллитов, особенно в средней части разреза, где они образуют пачки толщиной до 76 м. Аргиллиты обычно расслоены мергелями, наблюдается чередование аргиллитов и алевролитов темно-серого, серого цвета, участками - трещиноватых. Кроме этого, встречены карбонатные породы в виде чередующихся известняков (вакстоуна и мадстоуна) серого и темно-серого цвета. Толщина пород колеблется в пределах 150 м (Арман П-1) - 849 м (Северные Бузачи Г-7).

Пермо-триасовые отложения достаточно хорошо изучены как в пределах Бузачинского поднятия, так и на сопредельных территориях (В.Н. Кривонос, В.В. Липатова, Д.А. Кухтинов и другие) $[8,9]$. В составе верхней перми и триаса Северного Устюрта и Южного Мангышлака выделены три литолого-стратиграфических комплекса (снизу-вверх): красноцветный (верхнепермско-нижнетриасовый), пестроцветный (среднетриасовый) и сероцветный (верхнетриасовый). На Бузачинском поднятии красноцветный комплекс расчленяется на две части: нижняя - каражанбасская свита, условно сопоставленная с верхней пермью, верхняя - северобузачинская и бузачинская свиты, отнесенные к нижнему триасу, среднетриасовые выявлены лишь в отдельных разрезах, а верхнетриасовые - или отсутствуют по причине предъюрского размыва, или не накапливались в данном районе. 
Каражанбасская свита представлена сильно уплотненными аргиллитами и алевролитами с прослоями песчаников. В основании верхнепермского разреза скважины Северные Бузачи Г-7 присутствует довольно мощная (66 м) пачка базальных конгломератов, в составе которых наблюдаются гальки подстилающих каменноугольно-нижнепермских (ассельских) пород и андезитовых порфиритов. Похожая пачка базальных конгломератов встречена в скважине Арман П-1, в составе которых присутствует галька микробиальных баундстоунов. Сильная уплотненность пород, слагающих каражанбасскую свиту, четко фиксируется геофизическими параметрами, так пластовые скорости на глубинах, отвечающих рассматриваемой свите, достигают 5900 м/с в скважине Каламкас П-1, 6400 м/с - в скважине Северный Каражанбас П-1, 6800 м/с - в скважине Северные Бузачи Г-7. На электрокаротажных диаграммах свита выделяется повышенными значениями кажущегося сопротивления, в среднем составляющими 40 Ом.м и максимально - до 80 Ом.м. Толщина каражанбасской свиты, по данным бурения, превышает 600 м.

Северо-бузачинская свита (индский ярус нижнего триаса) распространена на полуострове Бузачи, наиболее изучена в скважине Каламкас П-1, Северные Бузачи П-1 и прослежена во всех скважинах месторождения Каражанбас Г-1, Г-2, Г-3. Она представлена переслаиванием песчаников, алевролитов, туфоалевролитов и смешанных песчано-алевролито-глинистых пород. Туфоалевролиты по составу терригенной составляющей близки к песчаникам, а туфогенный материал (20\%) представлен реликтами кислого вулканического стекла, оскольчатой кристаллокластической и слабо раскристаллизованной основной массой эффузивов. Для этих пород характерна пластовая скорость, равная 5200 м/с, удельное сопротивление - до 25 Ом/ м. Толщина свиты колеблется в пределах 660 - 900 м.

Бузачинская свита (оленекский ярус нижнего триаса) представлена переслаиванием аргиллитов, смешанных алевролито-глинистых разносностей, алевролитов, туфоалевролитов и песчаников. Окраска пород - темно-коричневая.

Разрез среднего триаса слагают пестроцветные песчано-глинистые породы с прослоями туфопесчаников и редко - карбонатных пород. Они выделены В.В. Липатовой в качестве каламкасской свиты, которая распространена лишь в пределах полуострова Бузачи [9], в составе которой выделены три подсвиты. Нижняя подсвита представлена серовато-коричневыми песчаниками, алевролитами, и аргиллитами. Подчиненную роль в ней играют прослои с примесью туфогеного материала. Средняя подсвита включает, преимущественно, сероцветные смешанные известковоалевропесчаные, известково-алевроглинистые породы, реже - известняки. Для толщи характерны прослои туфов и небольшое количество углефицированных растительных остатков. Верхняя подсвита, преимущественно, глинистая, имеет довольно низкие значения кажущегося сопротивления, не превышающие 5 Ом.м. Толщина каламкасской свиты составляет 400 - 790 м. Среднетриасовые отложения по сейсмическим данным наиболее уверенно выделяются на южном и северном склонах Бузачинского поднятия.

Общим для доюрских разрезов Бузачинского поднятия, вскрытых скважинами, является отсутствие пород-коллекторов и обильных нефтегазопроявлений. Лишь включения битума отмечены в породах ассельского яруса в разрезе скважины 
Северные Бузачи Г-7, в процессе бурения скважины Восточный Каратурун 1-П из отложений среднего карбона получен разгазированный фильтрат, в скважине Арман 1-П из триасовых и каменноугольных отложений поднят нефтенасыщенный песчаник, в призабойной части этой скважины (верхний девон) вскрыт газосодержащий трещиноватый известняк. На месторождении Каражанбас при проведении поисково-разведочных работ в 1975 году в двух скважинах - № 144 и №126 были опробованы шесть объектов в нижнетриасовых отложениях, в результате получены незначительные притоки нефти дебитами 0,034 и $0,34 \mathrm{~m}^{3} /$ сут, соответственно. В скважине Северные Бузачи Г-7 ассельские отложения с глубоким размывом и угловым несогласием перекрыты красноцветными базальными конгломератами верхней перми, сильно насыщенными включениями затвердевшей нефти.

Исследователи, занимавшиеся изучением тектоники и формированием Бузачинского свода, пришли к выводу, что по палеозойским отложениям этот район представляет собой фронтальную часть крупнейшей Карпинско-Бузачинской складчато-надвиговой системы, что резко снижает их перспективы нефтегазоносности [13].

Региональные геохимические исследования Карпинско-Бузачинской зоны, проведенные И.И. Аммосовым, Т.П. Волковой и др. (ИГиРГИ, г. Москва), показали, что палеозойские отложения отличаются повышенным тепловым потоком с максимальными палеотемпературами $180-350^{\circ} \mathrm{C}$ (стадия позднего метагенеза - верхнего апокатагенеза). Степень преобразованности нижнепермских отложений ОВ - значительная $(\mathrm{Ro}=1,25 \%)$, что соответствует постзрелой стадии $\mathrm{MK}_{5}$, то есть «газовому окну». Для каменноугольных пород преобразованность OB еще выше, значение Ro достигает $1,38-2,23 \%$, что приближается к апокатагенезу (стадия $\mathrm{AK}_{1}$ ), для девонских отложений Ro=2,19\% [14]. Таким образом, палеозойские породы в этой зоне поднятий не могут быть нефтематеринскими с хорошими нефтегенерирующими свойствами, так как они полностью реализовали свой нефтематеринский потенциал и находятся в постзрелой стадии («газовое окно»). Все залежи, сформированные в процессе эволюции этой структуры, вероятно, были разрушены при интенсивных тектонических подвижках.

Подтверждением бесперспективности доюрских отложений во вскрытых частях разреза служит отсутствие пород-коллекторов и нефтегазопроявлений в этой толще. Таким образом, палеозойские отложения в районе полуострова Бузачи признаны малоперспективными для обнаружения месторождений нефти и газа, соответственно, геологоразведочные работы на триас-палеозойский комплекс пород в настоящее время не проводятся. Получение притоков нефти из нижнетриасовых отложений в своде структуры Каражанбас можно объяснить положением нижнего уровня водо-нефтяного контакта, из которого видно, что продуктивные юрские горизонты облекают пермо-триасовую структуру, свод которой находится на абсолютных отметках 360 - 380 м (рисунок 4).

Самый нижний уровень ВНК залежи расположен ниже кровли триасовых отложений, на отметке минус 475 м. Можно предположить, что в результате латеральной миграции флюидов из погруженных зон, они могли скопиться и в верхних частях триасовых отложений, наиболее трещиноватых, поскольку на границе триас-юра отмечены значительные стратиграфические перерывы, связанные с размывами 


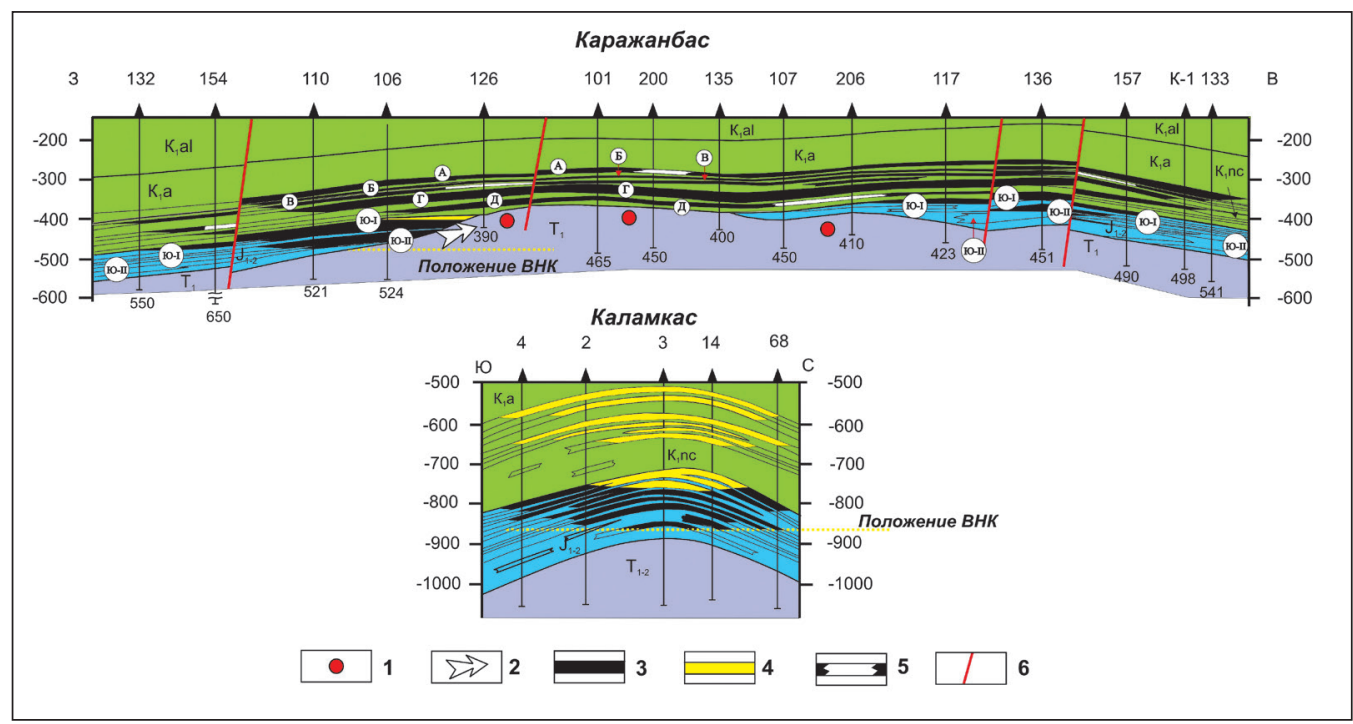

\section{Рисунок 4 - Возможное образование проявлений углеводородов \\ в триасовых отложениях Каражанбас \\ Условные обозначения: 1 - скопление углеводородов; \\ 2 - миграция углеводородов из юрских отложений}

пород. Для сравнения приведено месторождение Каламкас, где кровля доюрских отложений находится на абсолютных отметках 920 - 950 м, а уровень ВНК - значительно выше, на отметке минус 870 м. На этом месторождении признаки нефти и газа в доюрских отложениях не отмечены.

Комплексное изучение строения палеозойских структур в этом регионе, геохимических особенностей нефти месторождений Кашаган, Ауэзов, Каламкас-море, Хазар позволили сделать вывод, что нефть этих месторождений и нефть Бузачинского поднятия относятся к одному геохимическому типу, исходным органическом веществом для ее генерации могли служить породы морского генезиса. На основе этого высказано предположение, что залежи на Северном Каспии, а также бузачинские месторождения сформировались в результате миграции нефти и газа из Южно-Эмбинского (Тугаракчанского) прогиба, простирающегося вдоль Бузачинского поднятия, где глубина залегания фундамента достигает 12 км, а средне-верхнепалеозойские породы сложены карбонатно-глинистыми отложениями морского и прибрежно-морского происхождения $[15,16]$.

Свидетельством формирования залежей нефти и газа на Бузачинском поднятии в результате миграции углеводородов из прилегающих частей Прикаспийской впадины на севере Бузачинского поднятия служит факт их отсутствия на южном его склоне. В пользу точки зрения о перспективности северной и северо-западной частей Бузачинского поднятия свидетельствуют также многопластовые месторождения Арман и Каратурун Морской, расположенные в приморской части Бузачинского поднятия.

Не исключено, что формирование залежей в нижнемеловых и среднеюрских отложениях на Бузачинском поднятии происходило в несколько этапов. На первом этапе образовались скопления нефти и газа в палеозойских структурах, расположен- 
ных в пределах узкой карбонатной платформы, прогнозируемой в северной части поднятия. При дальнейших тектонических подвижках углеводороды мигрировали в сторону Бузачинского свода, заполняя на пути приразломные ловушки в палеозойских и мезозойских отложениях. В связи с тем, что прибрежная зона Каспийского моря изучена лишь гравиметрическими работами и отдельными сейсмическими профилями прошлых лет, рекомендуется проведение здесь сейсморазведочных работ с последующем бурением скважин.

\section{Выводы}

В северной части Бузачинского поднятия простирается с северо-запада на юг-восток узкой полосой палеозойская карбонатная платформа, зафиксированная геофизическими работами. Эта платформа, а также северные склоны Бузачинского поднятия, вероятно, претерпели значительные тектонические изменения в результате надвиговых процессов, происходивших в предкунгурский период. Предполагается многоэтапность формирования залежей нефти и газа. На первом, палеозойском этапе, вероятно, образовались залежи в пределах карбонатных структур, впоследствии произошло их переформирование и образование залежей в юрско-меловой толще. Перспективными являются северный и северо-западный склоны Бузачинского поднятия, где возможно существование приразломных ловушек. Наличие пород-покрышек сульфатного состава в нижнепермских отложениях значительно увеличивают вероятность нахождения здесь промышленных скоплений углеводородов.

\section{ЛИТЕРАТУРА}

1 Ажгалиев Д.К., Коврижных П.Н., Шагиров Б.Б., Каримов С.Г. Особенности строения и развития карбонатов в палеозое южного обрамления Прикаспийского бассейна // Известия УГГУ.- 2018. - Вып. 3(51). - С. 73-82. [Azgaliev D/K., Kovriznich P.N., Shagirov B.B., Karimov C.G. Osobennosti stroenija I razvitija karbonatov v paleozoe juznogo obramlenija Prikaspickogo basseina // Izvestija UGGU. - 2018. - Vyp. 3(51). - C.73-82].

2 Космодемьянский В.В., Салимгереев М.Ж., Авров В.П. др. Особенности строения доюрского структурного комплекса п-ва Бузачи в связи с перспективами нефтегазоносности // Геология нефти и газа. - 1995. - N 10. - С. 9-15. [Kosmodemjanskiy V.V., Salimgereev M.Z., Avrov V.P.i.dr. Osobennosti stroenija dojurskogo stryktyrnogo komplekca p-va Byzachi v cvjazi s perspektivami neftegazonosnosti // Geologija nefti i gaza. - 1995. - N 10. - S. 9-15.].

3 Попков В.И., Попков И.В. Перспективы обнаружения биогермных построек в доверхнепермских отложениях северной части полуострова Бузачи и прилегающей акватории Каспийского моря // Нефтегазовая геология. Теория и практика.- 2021. T. 16. - N 2. - C. 15. [Popkov V.I, Popkov I.V. Perspektivi obnaruzenija biogermnich postroek $v$ doverchnepermskich otlozhenijach severnoi chasti polyostrova Byzachi i prilegajuchcei akvatorii Kaspiyskogo moray // Neftegazovaja geologija. Teorijai praktika.2021. - T. 16. - N 2. - S. 15. s].

4 Попков В.И., Попков И.В. Литолого-стратиграфичекое расчленение и корреляция доверхнепермских отложений полеострова Бузачи // Геология, география и глобальная энергия. - 2021. - N 1. - С. 48-55. [Popkov V.I, Popkov I.V. Litologo- stratigraficheskoe raschlenenie i korreljazija doverchnepermskich otlozheniy polyostrova Byzachi // Geologija, geografija i global/naja energija. - 2021. - N 1. - S. 48-55]. 
5 Пронин А.П., Шестоперова Л.В. Нижнепермские отложения Северо-Каспийского поднятия (северная часть акватории Каспийского моря, Казахстан) // Недра Поволжья и Прикаспия. - 2020. - Вып. - С. 37-47. [Pronin A.P., Shestoperova L.V. Niznepermskieotlozhenija Severo-Kaspiiskogo podnjatija (severnaja chast/ akvatorii Kaspiiskogo morja, Kazachstan) // NedraPovolzh /ja i Prikaspija. - 2020. - Vyp. - C. 37-47].

6 Воцалевский Э.С., Шлыгин Д.А. Нефтегазовые системы осадочных бассейнов Казахстанского сектора Каспийского моря // Геология Казахстана. - 2004. N 3. C. 330-342. [Vozalevskiy E.S., Shliygin D.A. Neftegazoviye sistemiy osadochniych basseinov Kazachstanskogo sectora Kaspiyskogo moray // Geologija Kazachstana. 2004. N 3. - S. 330-342].

7 Виноградова К.В., Цатурова А.А. Палиностратиграфия и палеогеография доюрских отложений Западного Казахстана (п-ов Бузачи) // Палинология в биостратиграфии, палеоэкологии и палеогеографии. Тезисы докладов 8-й Всероссийской палинологической конференции. Москва, 1996. - С. 28-29. [Vinogradova K.V., Zcaturova A.A.Palinologija $\vee$ biostratigrafii, paleoekologii ipaleogeografii. Tezisiy dokladov 8-iy Vserossiiskoiy palinologicheskoi konferenzii.Moskva. 1996. - S. 28-29].

8 Кухтинов Д.А., Киселевский Ф.Ю., Леонова Е.Г. Стратиграфия триасовых отложений Северо-Устюртской впадины // Известия АН СССР. Серия геологическая. - 1978. - N 2. - C. 7-78. [Kuchtinov D.A., Kiselevskiy F.Y., Leonova E.G. Stratigrafija triasovich otlozeniy Severo-Ustuyrtskoiy vpadini // Izvestiya AN SSSR. Serija geologicheskaja. 1978. - N 2. - C. 7-78].

9 Липатова В.В., Волож Ю.А., Воцалевский Э.С. и др. Доюрский комплекс Северного Устюрта и полуострова Бузачи. Труды ВНИГНИ, № 254 М.: N 254. - М., 1985. - 133 с. [Lipatova V.V., Volozh U.A., Vozalevskiy E.S. Dojurskiy kompleks Severnogo Ustuyrta i polyostrova Byzachi. Trydi VNIGNI, N 254. - M., 1985. - 133 s.].

10 Пронин А.П., Турков О.С., Калмуратова С.А., Милькина Н.В. Новые данные о условиях образования палеозойских отложений п-ва Бузачи // Геология Казахстана. 1997. - N 4. - S. 43-52. [Pronin A.P., Turkov O.S.,Kalmuratova S.A., Mil/kina N.V. Novie Dannie o yslovijach obrazovanija paleozoiskich otlozheniy p-va Byzachi // Geologija Kazachstana. - 1997. - N 4. - s. 43-52.

11 Серебрянская М.А. Спорово-пыльцевые комплексы нижнетриасовых отложений Устюрта, Южного Мангышлака, полуострова Бузачи и их стратиграфическое значение // Бюлл. МОИП. Отд. геол. - 1981. - Т. 56. - Вып. 5. - С. 105-108. [Serebrjanskaja M.A. Sporo-piyl/zevie kompleksiy nizhnetriasovich otlozheniy Ustujrta, Juzhnogo Mangisclaka, polyostrova Byzachi i ich stratigraficheskoe znachenie //Bjull.MOIP. Otd.geol. - 1981. - T. 56. - Vyp. 5. - S. 105-108].

12 Серебрянская М.А. Спорово-пыльцевые комплексы среднетриасовых отложений Устюрта, полуострова Бузачи и их стратиграфическое значение. // Бюлл. МОИП. Отд. геол. - 1982. - Т. 57. - Вып. 6. - С. 62-65. [Serebrjanskaja M.A. Sporo-piyl/zevie kompleksiy srednetriasovich otlozheniy Ustujrta, polyostrova Byzachi i ich stratigraficheskoe znachenie // Bjull.MOIP. Otd.geol. - 1982. - T. 57. - Vyp. 6. - S. 62-65].

13 Глумов И.Ф. Маловицкий Я.П., Новиков А.А. Сенин Б.В. Региональная геология и нефтегазоносность Каспийского моря. - М., Недра, 2004. - 341 с. [Glumov I.F., Malovizkiy Ja.P., Novikov A.A., Senin B.V. Regional/naja geologija i neftegazonosnost/ Kaspiiskogo morja. - M.,Nedra. 2004. - 341 s].

14 Аммосов И.И., Гречишников Н.П., Горшков В.И., Волкова Т.П. и др. Палеогеотермия и нефттеносность. - М.: Наука, 1982. - 108 с. [Ammosov I.I., Grechichcnikov N.P.,Gorchkov V.I.,Volkova T.P. i dr. Paleogeotermija i neftegazonosnost/. - M.:Nauka, 1982. - 108 s]. 


\section{ГЕОЛОГИЯ}

15 Куандыков Б.М., Турков О.С., Шестоперова Л.В. Геологическое строение и оценка углеводородного потенциала северо-восточного сегмента Каспийского моря (в пределах Казахстана) // Геология регионов Каспийского и Аральского морей. Алматы. «КазГео», 2004. - с.224-236. [Kyandikov B.M., Turkov O.S., Shestoperova L.V. Geologicheskoe stroenie i ozenka uglevodorodnogo potenziala severo-vostochnogo segmenta Kaspijskogo morja (v predelach Kazachstana) // Geologija regionov Kaspijskogo i Aral/skogo morei. -Almaty: KazGeo. 2004. - s.224-236].

16 Остроухов С.Б., Крашакова А.В., Бочкарев А.В. Концепция формирования залежей углеводородов Северного Каспия в юрско-меловом комплексе отложений // Геология и разработка месторождений Нижнего Поволжья и Северного Каспия. Труды «ВолгоградНИПИморнефть». Вып.70, - Волгоград, 2011. - С. 72-87. [Ostrouchov S.B., Krashakova A.V., Bochkarev A.V. Konzepzija formirovanija zalezhei uglevodorodov Severnogo Kaspija v jursko-melovom komplekceotlozhenij // Geologija I razrabotka mestorozhdeni Nizhnego Povolzh/ja b Severnogo Kaspija / Trudiy Volgograd NIPImorheft/. Viyp.70, - Volgograd, 2011. - S. 72-87]. 